\title{
American Calculations of Battleline Strength, 1941-2
}

\section{Alan D. Zimm}

Il y a une notion populaire que l'attaque aérienne japonaise sur Pearl Harbor a irrévocablement accompli deux choses, l'une matérielle et l'autre doctrinale: elle a annihilé la ligne de bataille américaine, et elle a résolu le débat porte-avions d'entre-deux guerres contre cuirassés et a donc conduit les dirigeants navals à la conclusion ferme que les cuirassés étaient désuets. Ces points de vue ont été évidemment confirmés par le fait que les cuirassés américains n'ont pas été commis au combat purement maritime dans le Pacifique jusqu'à la fin de 1942.

Les deux perceptions sont erronées. La plupart des cuirassés américains ont survécu Pearl Harbor. Elles n'ont pas été immédiatement utilisées pour un certain nombre de raisons. Les calculs basés sur la formation reçue par la plupart des cadres supérieurs des États-Unis prouveraient que la ligne de bataille des États-Unis avait perdu sa marge de puissance assurant la défaite de la ligne de bataille japonaise. La logistique a gardé les cuirassés lents, gourmands de nourriture et de carburant, près de leurs sources d'approvisionnement.

There is the popular perception that the Japanese air attack on Pearl Harbor irrevocably accomplished two things, one material and one doctrinal: it annihilated the American battleline, and it resolved the interwar carriers versus battleships debate driving naval officers to the firm conclusion that battleships were obsolete. These views were evidently confirmed by the fact that American battleships were not committed to surfaceto-surface combat in the Pacific until the end of 1942.

Both perceptions are wrong. Most of the American battleline survived Pearl Harbor. They were not immediately employed for a number of reasons. Calculations based on the training most U. S. flag officers received would show that the U.S. battleline had lost its assured margin of power to defeat the Japanese battleline. Logistics kept the slow, food- and oil-hungry battleships near their sources of supply.

\section{Numbers behind the fleets}

The Washington Naval Conference of 1922 established tonnage limitations for capital ships between the great naval powers. The United States was allocated 525,000 tons of battleships and Japan 315,000 tons, a ratio of approximately 10:6. Political leaders saw these limitations as a way to head off another monstrously expensive 
building race. Within that context, the naval leadership pressed for force ratios that would meet their nation's security needs. These ratios were critical: the needs of one nation would inevitably conflict with those of their potential opponents.

In the Pacific, some Japanese naval strategists originally demanded a 10:7 ratio based on the assumption that an approaching enemy fleet required at least 50 percent superiority over a defending fleet. With this ratio an attacking American fleet would be $10 / 7=43$ percent greater than the size of the Japanese fleet, not quite enough to ensure an American victory. ${ }^{1}$ When the 10:6 ratio was fixed in the treaty it became an issue of great contention and discord. The Japanese naval leadership sought to overcome their perceived force level deficiency through three initiatives: first, by intensive training designed to raise their fleet to fanatical standards of efficiency; second, by making their new construction ships ton-for-ton qualitatively superior to their American opponents; and third, by employing an attrition strategy of "ambush and decrease" designed to bleed away the American's force superiority prior to the decisive battleline confrontation. ${ }^{2}$

The Americans had their own assumptions and calculations. One assumed that a force would lose 10 percent of its effectiveness for every 1,000 nautical miles it operated away from its primary base, due to lack of maintenance, bottom fouling, reduced morale, enemy attacks en route, and other factors. ${ }^{3}$ The American fleet would lose 30 percent effectiveness if it fought the Japanese in the Western Pacific, so in their view a 10:7 initial force ratio would actually translate into 7:7, or equality in battle. ${ }^{4}$ The 10:6 ratio allowed the Americans to believe they could provide a measure of security for their possessions in the Philippines, and deter Japanese expansionism. ${ }^{5}$ But this $7 / 6=16.7$ percent force superiority was considered on the cusp of adequacy. War games of a direct movement to the Philippines generally showed that that approach could result in disaster, and overall the level of risk was unpalatable. ${ }^{6}$ Eventually, the agreed strategy was a progressive phased move across the Pacific, establishing intermediate bases along the way, an unspectacular strategy leading to a reliable victory.

By 1941 the situation had changed greatly. During the 1920s and early 1930s the

1 Sadao Asada, From Mahan to Pearl Harbor: The Imperial Japanese Navy and the United States (Annapolis, 2006), 48.

2 David C. Evans and Mark R. Peattie, Kaigun: Strategy, Tactics, and Technology in the Imperial Japanese Navy 1887-1941 (Annapolis, 1997), 187.

3 Asada, 48. See also John T. Kuehn, Agents of Innovation: The General Board and the Design of the Fleet That Defeated the Japanese Navy (Annapolis 2008), 26.

4 Note that the rule of thumb was not so precise as to define whether the 30 percent loss in effectiveness was a multiplier against the initial or current fleet effectiveness, or an amount to be subtracted. Contemporary usage appears to favor the subtractive application.

5 Asada, 56.

6 See the extensive discussion of the strategies of the "thrusters" and the "cautionaries" in Edward S. Miller, War Plan Orange: The U.S. Strategy to Defeat Japan, 1897 - 1945 (Annapolis, 1991). The "cautionaries," advocating a step-by-step advance instead of a shortwar direct thrust to the Philippines, won the debate and the step-by-step advance was Navy strategy from 1934 on. 
Japanese, using war gaming and map maneuvers likely inspired by similar programs in Germany and at the U.S. Naval War College (N.W.C.), extensively gamed "ambush and decrease." Never once were they successful in locating the American fleet and anticipating its route precisely and quickly enough to concentrate attacks by light forces and submarines that were their key to victory. The failure of "ambush and decrease" meant that the 10:6 ratio was a threat to Japanese security and ambitions; there were calls to cancel Japanese participation in the Treaty system. The cancellation of the treaty also likely became a necessity when Japanese ship designs, attempting to achieve unit-to-unit superiority, came in seriously overweight and violated Treaty limits. Carriers Hiryu and Soryu were listed at 10,500 tons when they actually exceeded 18,000; the Nachi class violated the 10,000-ton cruiser limitation by at least 1,000 tons, more likely 3,000.

In 1934 Japan announced its intention to withdraw from the 1922 Washington and 1930 London naval treaties upon their expiration in 1936. The Japanese navy immediately began design work on battleships that greatly exceeded previous treaty limitations in tonnage and main battery guns.

Meanwhile, the United States had not built up to her allowable treaty tonnage in cruisers and destroyers, and was "voluntarily" maintaining the Washington and London naval treaty limitations for other classes. The fleets in 1936 were close to a 10:7 ratio in overall tonnage, the level with which the Japanese felt they could win a war.

With the rise of Nazi Germany, the beginning of the Second World War in Europe, and Japan's aggressions in China and Manchuria, the Americans began a building program that first authorized expansion of the fleet to the Treaty limits, then initiated a massive expansion to build a "Two Ocean Navy." In June 1940 a doubling of the aggregate tonnage of the fleet was authorized; by February of 1941 Congress had authorized construction of 368 new combatants and 338 other ships. ${ }^{7}$ December 1941 saw 82 new hulls under construction (table 1) with the promise of many more to come. The Japanese saw that their "favorable" 10:7 ratio was not to last.

\begin{tabular}{|l|c|c|c|c|c|}
\hline & Battleships & Carriers & Heavy Cruisers & Light Cruisers & Destroyers \\
\hline USA & 8 & 5 & 4 & 22 & 43 \\
\hline Japan & 4 & 3 & 1 & 4 & 9 \\
\hline
\end{tabular}

Table 1: Surface Warships under Construction, 1 December 1941

\section{Pearl Harbor and Historians}

Admiral Yamamoto, commander-in-chief of the Japanese Combined Fleet, articulated several objectives for the Pearl Harbor attack. One was to sink American battleships as a devastating blow against American morale, which he presumed would eventually lead to a negotiated settlement acknowledging Japan's dominance of the Western Pacific. Another was to immobilize the American Pacific fleet so that it would not be a threat to the flank of the southward advance for at least six months.

7 Joel R. Davidson. The Unsinkable Fleet: The Politics of U.S. Navy Expansion in World War II (Annapolis, 1996), 22. 
Some refer to the outcome of the attack on Pearl Harbor as if the American battleline was totally annihilated. Even highly respected authors have made sweeping statements like, "In the Japanese attack on Pearl Harbor in 1941, the U.S. Navy battle line was destroyed." According to another author, "Pearl Harbor had been reduced to a pile of smoking rubble and sunken ships." ${ }^{\prime}$ One claimed that "...like a flashing samurai word [the Japanese at Pearl Harbor] decapitated the U.S. Fleet." 10 Another stated that the losses at Pearl Harbor forced the American battle fleet to rely on only three old and two newly constructed battleships. ${ }^{11}$ Such sweeping conclusions leave little question as to why American battleships did not make an appearance as surface combatants until late in the Guadalcanal campaign, and then only in penny packets.

In fact, the American battleline was not annihilated. Before Pearl Harbor, the fleet had seventeen battleships in commission, of which only eight were at Pearl Harbor. In the attack five were sunk (of which three were later raised and recommissioned) and three more damaged. The three damaged battleships were repaired and returned to service in only three or four months - they could have fought sooner, but with the Japanese battleline ensconced in home waters time was available for upgrades and modifications. Maryland and Tennessee returned to service on 26 February and Pennsylvania on 30 March 1942, much improved with state-of-the-art surface search and fire control radars, new fire direction equipment, strengthened anti-aircraft batteries, and modern fighting tops. They joined three battleships from the Atlantic fleet, Idaho, Mississippi, and New Mexico, the most powerful of the Treaty fleet battleships that had been extensively modernized during the 1930s. ${ }^{12}$ These battleships were equipped with the same fire control equipment and radars that proved so effective on the night of 14-15 November 1942 at Guadalcanal, where the new battleship Washington pounded the Japanese fast battleship Kirishima into scrap. ${ }^{13}$

On 7 January 1942 Nimitz formed Task Force 1 and began gathering battleships at San Francisco into a cohesive unit for training. In short order Task Force 1 comprised seven battleships. ${ }^{14}$ Four months after Pearl Harbor, the Americans could have mustered a battleline of twelve battleships. By April 1942 three additional new battleships had

8 Trent Hone, "The Evolution of Fleet Tactical Doctrine in the U.S. Navy, 1922-1941," Journal of Military History 67 (October 2003), 1107.

9 Bernard Edwards, Japan's Blitzkrieg: The Allied Collapse in the East 1941-42 (New York, 2006), 14.

10 Robert L. O'Connell. Sacred Vessels: The Cult of the Battleship and the Rise of the U.S. Navy (New York, 1991), 314.

11 Kenneth Poolman. The Winning Edge: Naval Technology in Action, 1939 - 1945 (Annapolis, 1997), 130.

12 Norman Friedman, U.S. Battleships: An Illustrated Design History (Annapolis, 1985), 346387.

13 David C. Fuquea. "Task Force One: The Wasted Assets of the United States Pacific Battleship Fleet, 1942," Journal of Military History 61 (October 1997), 710.

14 John B. Lundstrom, Black Shoe Carrier Admiral: Frank Jack Fletcher at Coral Sea, Midway, and Guadalcanal (Annapolis, 2006), 74. 
been commissioned and were in workups. Shortly thereafter the American battleline could have been restored to the same numbers as the pre-war Treaty fleet, yet more powerful by the substitution of five modern 16-inch-gun ships for the five older battleships sunk at Pearl Harbor. Against this the Japanese had their Treaty fleet, six battleships and four reconstructed but more lightly armored battlecruisers, along with one new construction ship. (This last ship, Yamato, was an unknown to Allied intelligence: in 1942 they under-estimated her at 45,000 tons carrying nine 16-inch guns, a mirror of the Americans' own Iowa class battleships. ${ }^{15}$ ) By the second half of 1942 the United States Navy could have put fifteen battleships to sea to confront eleven Japanese.

Some historians have suggested that, after Pearl Harbor and the loss of the British battleship Prince of Wales and battlecruiser Repulse to Japanese land-based torpedo bombers, carriers were instantly vaulted to supremacy in the minds of naval officers, and battleships just as quickly rendered obsolete and irrelevant. ${ }^{16}$ One respected historian referred to the Treaty battleships as "dinosaurs." 17 The venerable Morison, contemporary to the events, put it this way: "The stock of the battlewagons went down, air power advocates were jubilant, and the half-truth 'Capital ships cannot withstand land-based air power' became elevated to the dignity of a tactical principle that none dared take the risk to disprove." ${ }^{18}$ These statements could lead to the supposition that American strategists rightly consigned the battleships to minor, secondary roles (such as shore bombardment or anti-aircraft protection for carriers) and were loath to consider their employment in their designed role.

This was not the case. Indeed, U.S. commands took care in deploying the battleships to execute tasks that carriers could not accomplish. Carriers were powerful in daylight, but battleships dominated the night; carriers were fragile and could not stand up to surface gunfire, and commanders would not risk them in confined seas. Battleships were needed to counter other battleships in areas like the Arctic Sea, where weather conditions and extended hours of darkness often prevented air operations.

In the Pacific, there were repeated calls, particularly by the chief of naval operations and commander-in-chief of the U.S. Fleet, Admiral E.J. King, to move Pacific Fleet battleships forward and employ them against Japanese surface units. King, a naval aviator who had commanded a carrier pre-war, insisted that battleships be included in the planned offensive operations. The Pacific Fleet staff seriously studied the employment of the battleships while watching the progress of their training. A combined carrierbattleship strike on Truk was considered, along with efforts against the Bonin Islands or Saipan. In April 1942 the deployment of a battleship division to New Zealand was examined, along with operating the battleline in concert with the Lexington task force in

15 Division of Naval Intelligence, ONI 41-42, List of Japanese Vessels by Design Classes.

16 See Wilbur H. Morrison, Pilots, man your planes!: The History of Naval Aviation (Annapolis, 1999) for some overheated rhetoric on this subject.

17 Lundstrom, 75.

18 Samuel Eliot Morison, The Rising Sun in the Pacific 1931 - April 1942 (1948; repr.,Edison NJ, 2001), 190. 
the Central Pacific. ${ }^{19}$ In another instance, Admiral King recommended that a carrier task group be formed with Treaty battleships escorting Saratoga.

These proposals were generally foiled by four considerations. First, there was a lack of sufficient logistics support, particularly oil tankers. Second, the older Treaty battleships did not have the speed to keep up with a carrier task force, and thus were unsuited to the kind of hit-and-run warfare the American strategic situation demanded. Third, there was a dearth of escort ships, cruisers and destroyers, to fill out a properly balanced task force. Fourth, there was reluctance on the part of Admiral C.W. Nimitz, commander-in-chief Pacific Fleet, to risk these units in confined waters. ${ }^{20}$ Operations in confined waters threw away one of the battleship's greatest advantages, gun range, while possibly allowing cruisers and torpedo-carrying destroyers to close within effective range of their weapons. That is what happened in the night action off Guadalcanal on 13 November 1942 when a force of U.S. cruisers brutalized to immobility the Japanese battleship Hiei, leading to her destruction. ${ }^{21}$

The reluctance to risk battleships was a reflection not of their weakness but of their value: they were not considered as expendable units. The battleships were allowed to take fewer day-to-day risks than cruisers and destroyers because they had to be preserved to stand up to their natural opponent, the enemy battleships, a force that early in the war the Japanese seemed intent on preserving for a future "decisive battle" they expected to climax the war.

But did American naval officers consider their available battleline to have sufficient power to take on the Japanese in a contest of battlelines, and win?

This is an important question. It can lead to a better understanding of why American battleships were employed as they were during the first months of the war in the Pacific. If the Americans believed that their battleship force could have defeated the Japanese battleline in 1942 or 1943, it opens the question of why they were not so employed.

\section{Calculating the relative effectiveness of the battlelines}

In the early 1920s the Naval War College developed an advanced system for evaluating the worth of individual ships in the line of battle. The desire for realistic rules for playing tactical war games required a system for accurately determining a ship's firepower and its effect on other warships. The system was also used to measure the relative fighting strength of fleets. These calculations can be reproduced using the college's June 1936 "Blue and Orange Fleet" data booklet, the 1934 "Fire Effect Tables," and the March 1935 "Gun Data: Limiting Ranges for Armor Penetration" tables, which

19 Lundstrom, 74, 116.

20 Fuquea, particularly 717-718.

21 James W. Grace, The Naval Battle of Guadalcanal: Night Action, 13 November 1942 (Annapolis, 1999); Paul S. Dull, A Battle History of the Imperial Japanese Navy (19411945) (Annapolis, 1978). 
were current for pre-war calculations. ${ }^{22}$

"Fighting Strength" (FS) was a means of evaluating the worth of a vessel as a gun platform. This was not a simple number, but a variable that changed according to the range, target angle, and armor protection of the opponent. Fighting Strength was a multiple of two terms, the "Life" (L) of the ship multiplied by its "Hitting Power" (HP).

The Life of the ship was determined as a number of "equivalent penetrative 14inch shell hits" - the formula for this is presented in Appendix 1. "Hitting Power" was determined by multiplying three terms: the normal battle rate of fire at the given range, the percentage of hits at that range, and the hit value (HV):

$$
\mathrm{HP}=(\mathrm{ROF})(\% \text { Hits })(\mathrm{HV})
$$

The Naval War College had a large library of pre-calculated tables of these factors, based on engineering calculations and target practice experience, for all the guns of the major navies. There were also extensive tables showing the armor penetration capability of shells with respect to range and target angle. Shells that penetrated armor were given a higher hit value.

The Naval War College Maneuver Rules and the Fighting Strength calculations were unique and innovative analytic tools far in advance of those used in other navies. This system was used to report on the relative capabilities of Blue (USN) versus Orange (Japan), and Blue versus Red (Great Britain), and used for force level studies and to develop operational plans and courses of action. New tactical concepts were developed for example, the circular screen was first examined in tactical war games before it was introduced in the fleet. ${ }^{23}$ The system was an integral part of the ship design process alternate designs were evaluated in an assortment of scenarios, and recommendations forwarded as to which the Naval War College analysis teams felt performed best. These studies were often done for the General Board, or at the direct request of the chief of naval operations. The models and calculations gained in sophistication and usefulness over the interwar years, eventually becoming an influential part of policy decision making and a powerful tool in training future naval leaders.

An example of its significance can be seen from an event early in its history. In October 1922 the Bureau of Ordnance reported that the fleet was at a serious disadvantage when measured against the longer ranged guns of the British fleet. ${ }^{24}$ The Navy requested funding to modernize battleships' main battery turrets to allow increased gun elevation for greater range. Congress initially denied the requests, citing two concerns: whether it was allowed under the Washington Naval Treaty, and whether it was worth doing. In response to the second question, Captain (later Admiral) Joseph Reeves, the head of the N.W.C. Tactics Department, produced plots showing the Fighting Strength of the two fleets, and calculated their relative Fighting Strength, at ranges from 15,000 to

22 The Naval War College analytic methods are covered in more detail in Alan D. Zimm, "Build the Limit: The American 'Maximum Battleship' Designs of 1916-1917," Warship International No. 1 (1975), 31-59.

23 E.B. Potter, Nimitz (Annapolis, 1976).

24 Kuehn, 79. 
33,000 yards. These plots, one of which is recreated in chart 1, calculated the British fleet's Fighting Strength at between three to six times that of the U.S. fleet at ranges between 24,000 and 30,000 yards, ranges at which, with aircraft spotting and new analog computer fire control systems, were becoming practical. Reeves concluded that "Once in the fatal zone the BLUE fleet can not escape by means of her speed, nor fight off the RED fleet by means of her guns." ${ }^{25}$ After presentation to the General Board and circulation among the naval staff in Washington, these calculations very likely went a long way towards convincing Congress of the value of the turret modernization program. In March 1926 Congress authorized funds to upgrade the first of the battleships. ${ }^{26}$

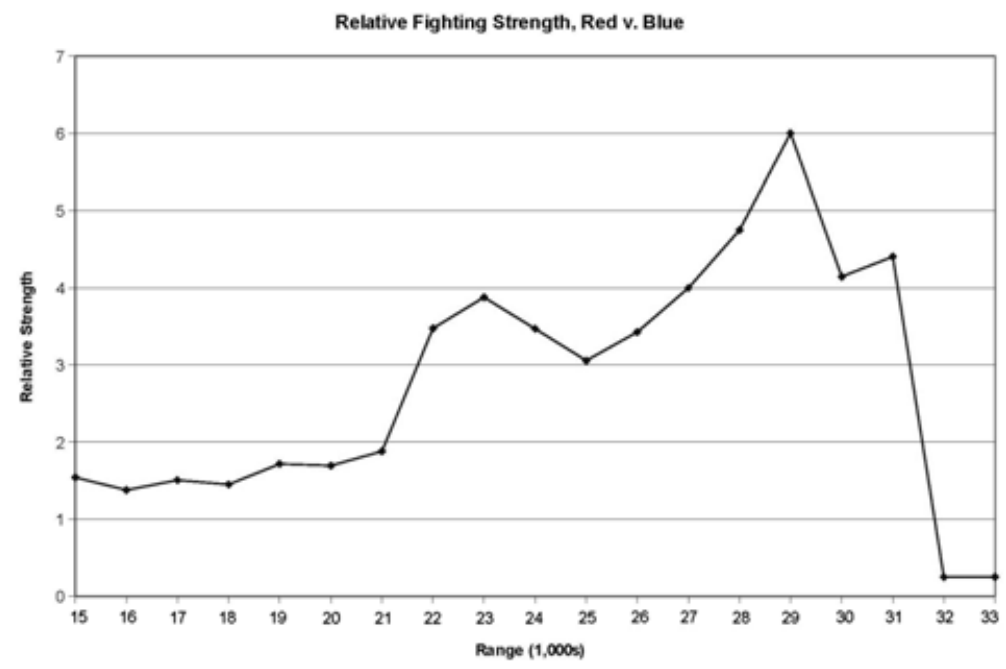

Chart 1: Fighting Strength of the British divided by that of the U.S. battleline with respect to range, calculated by the NWC, 1925

At the college, the war game was the core of the curriculum. Officers in both the junior and senior courses played a number of these games, both on the strategic and tactical level. The games provided the officers with a concept of what to expect in warfare from the campaign level down to the battle: for a decision pitting force "A" against force "B," they could expect result "C." It was a significant step beyond mere opinions.

As a guide to policymakers, the Fighting Strength calculations were not perfect. They provided a single value comparison of the relative gunnery strength of a ship, which was useful for its specific application, but was not an overall picture of the effectiveness of a ship as a fleet unit. It did not include such important factors as a ship's secondary and anti-aircraft batteries, speed, and the quality of its underwater protection. The

25 Captain J.M. Reeves, "A Tactical Study Based on the Fundamental Principles of War of the Employment of the Present BLUE Fleet in Battle Showing the Vital Modifications Demanded by Tactics," 36, quoted in Michael Vlahos, The Blue Sword: The Naval War College and the American Mission, 1919 - 1941(Washington, D.C., 1980), 118.

26 Thomas Wildenberg, All the Factors of Victory: Adm. Joseph Mason Reeves and the Origins of Carrier Air Power (Washington, D.C., 2003), 112-116. 
Fighting Strength calculations of the battle line as a whole also did not include the contributions of supporting units, and ignored torpedo and aerial warfare. Most significantly, it was an "expected value" model containing no random elements. The models were deterministic, representing the average of the anticipated results, without the influence of lower probability "catastrophic" hits that could result in magazine explosions, jammed rudders, or destroyed screws. ${ }^{27}$ Pre-war, the fire effect tables were not recalculated to include the improved accuracy of radar-directed gunnery.

But even considering their weaknesses, the Fighting Strength calculations, and war gaming system as a whole, was a powerful first step to substitute calculation where there formerly was only opinion. As a move to understand naval warfare analytically, it was a magnificent advance, the first of its kind, groundbreaking, and the true beginning of the science of naval operations research.

The "Blue and Orange Fleet" data book was an intelligence publication that provided comprehensive statistics on the opposing fleets. Each ship had data on tonnage, fuel, speeds, radius at sustained and economical speeds, complement, "Life," armament, and armor, all updated to account for modernizations and newly acquired intelligence. Like all intelligence products, the data had its share of errors. For example, the data for Japanese armor sometimes overestimated belt armor and underestimated deck armor, sometimes by as much as three inches. In addition, the single values for deck and belt armor were a simplification, as often ships would have different armor thicknesses protecting different areas. Gun data tended to "mirror image" capabilities, where the performance of a Japanese 16-inch/45 caliber was nearly identical to the similar American gun, as were torpedo performance figures. Overall, however, the data was remarkably accurate, considering that most of it had to be calculated from ships' size and draft estimates mostly taken from photographs.

Tables 2 and 3 contain some of the data for the Treaty fleets for the Blue and Orange battlelines contained in the 1936 estimates, including the errors in Japanese protection. These errors will remain in this analysis in order to calculate the figures that actually informed the decision makers of the time.

The column "Immunity" refers to the calculation of the armor protection Immunity Zone. That is the zone where the armor protection of the ship is not penetrated by the opposing ship's guns listed in the "Enemy Gun" column. The Immunity Zone changes for each combination of guns and armor protection - for different ship versus ship matches. In this case, the ships are paired off in the order shown in the tables, with the most powerful ships in the U.S. battleline matched against the most powerful of the Japanese ships, the standard N.W.C. procedure. For example, Mutsu's "22-34" Immunity Zone means that when Mutsu is engaged by the West Virginia's 16-inch/45 main battery, Mutsu's belt armor is penetrated at under 22,000 yards and its deck armor penetrated at ranges over 34,000 yards - between 22,000 and 34,000 yards is the Immunity Zone, considered safe from penetrating rounds.

27 The N.W.C. was aware of a number of these shortcomings, particularly the problems with the expected value methodology and lack of catastrophic hits. At least one paper was written proposing solutions, but further action to change the rules was overtaken by the war. 


\begin{tabular}{|l|c|c|c|c|c|c|c|}
\hline Name & Life & \# Guns & Main Bat & Belt armor & Deck armor & Immunity & Enemy Gun \\
\hline $\begin{array}{l}\text { Vest } \\
\text { Virginia }\end{array}$ & 18.5 & 8 & $16 " / 45$ & 13.5 & 3.42 & $22-20$ & $16 " / 45$ \\
\hline Maryland & 18.5 & 8 & $16 " / 45$ & 13.5 & 3.42 & $22-20$ & $16 " / 45$ \\
\hline Colorado & 18.5 & 8 & $16 " / 45$ & 13.5 & 3.42 & $14-22$ & $14 " / 45$ \\
\hline California & 17.7 & 12 & $14 " / 50$ & 13.5 & 3.42 & $14-22$ & $14 " / 45$ \\
\hline Tennessee & 17.7 & 12 & $14 " / 50$ & 13.5 & 3.42 & $14-22$ & $14 " / 45$ \\
\hline Idaho & 17.3 & 12 & $14 " / 50$ & 13.5 & 4.87 & $14-27$ & $14 " / 45$ \\
\hline Mississippi & 17.3 & 12 & $14 " / 50$ & 13.5 & 4.87 & $14-27$ & $14 " / 45$ \\
\hline New Mexico & 17.3 & 12 & $14 " / 50$ & 13.5 & 4.87 & $14-27$ & $14 " / 45$ \\
\hline Arizona & 17.1 & 12 & $14 " / 45$ & 13.5 & 3.96 & $14-24$ & $14 " / 45$ \\
\hline $\begin{array}{l}\text { Pennsylvani } \\
\text { a }\end{array}$ & 17.2 & 12 & $14 " / 45$ & 13.5 & 3.96 & $14-24$ & $14 " / 45$ \\
\hline Oklahoma & 16.1 & 10 & $14 " / 45$ & 13.5 & 4.18 & $14-25$ & $14 " / 45$ \\
\hline Nevada & 16.1 & 10 & $14 " / 45$ & 13.5 & 4.18 & $14-25$ & $14 " / 45$ \\
\hline Texas & 15.5 & 10 & $14 " / 45$ & 12 & 3.42 & $16-22$ & $14 " / 45$ \\
\hline New York & 15.5 & 10 & $14 " / 45$ & 12 & 3.42 & $16-22$ & $14 " / 45$ \\
\hline Arkansas & 15.3 & 12 & $12 " / 50$ & 11 & 3.42 & $18-22$ & $14 " / 45$ \\
\hline Total & 255.6 & 160 & & & & & \\
\hline
\end{tabular}

Table 2: U.S. Battleline statistics

\begin{tabular}{|l|c|c|c|c|c|c|c|}
\hline Name & Life & \# Guns & Main Bat & Belt armor & Deck armor & Immunity & Enemy Gun \\
\hline Mutsu & 18.8 & 8 & $16 " / 45$ & 13 & 6 & $22-34$ & $16 " / 45$ \\
\hline Nagato & 18.8 & 8 & $16 " / 45$ & 13 & 6 & $22-34$ & $16 " / 45$ \\
\hline Ise & 16.3 & 12 & $14 / 45$ & 12 & 3.75 & $25-25$ & $16 " / 45$ \\
\hline Hyuga & 16.3 & 12 & $14 / 45$ & 12 & 3.75 & $21-25$ & $14 " / 50$ \\
\hline Yamashiro & 16.2 & 12 & $14 / 45$ & 12 & 5 & $21-31$ & $14 " / 50$ \\
\hline Fuso & 16.2 & 12 & $14 / 45$ & 12 & 5 & $21-31$ & $14 " / 50$ \\
\hline & & & & & & $21-31$ & $14 " / 50$ \\
\hline Kirishima & 12 & 8 & $14 / 45$ & 8 & 6 & $31-33$ & $14 " / 50$ \\
\hline & & & & & & $30-33$ & $14 " / 45$ \\
\hline Haruna & 12 & 8 & $14 / 45$ & 8 & 6 & $30-33$ & $14 " / 45$ \\
\hline & & & & & & $30-33$ & $14 " / 45$ \\
\hline Kongo & 12 & 8 & $14 / 45$ & 8 & 6 & $30-33$ & $14 " / 45$ \\
\hline & & & & & & $30-33$ & $14 " / 45$ \\
\hline Hiei & 12 & 8 & $14 / 45$ & 8 & 6 & $30-33$ & $14 " / 45$ \\
\hline \multicolumn{1}{r|}{ Total } & 150.6 & 96 & & & & $23-33$ & $12 " / 50$ \\
\hline
\end{tabular}

Table 3: Japanese Battleline statistics

Chart 2 shows a graphic comparison of the Immunity Zones of the opposing Treaty battlelines. The black bars show the U.S. ships' Immunity Zones, with grey for the Japanese. In two cases there are no bars, that of West Virginia targeted by Mutsu's 16inch guns, and Colorado engaged by Nagato's 16-inch guns. West Virginia and Colorado 
did not have an Immunity Zone against the Japanese 16-inch guns - they both had belt protection over 22,000 yards and deck protection under 20,000 yards, so there wasn't a range at which both deck and belt armor provided protection. But the rest of the U.S. ships had substantial Immunity Zones against Japanese 14-inch guns, mostly beginning at 13,000 yards and in some cases as far as 27,000 yards. The chart covers ranges only to 30,000 yards, as the N.W.C. did not expect effective fire at longer ranges. ${ }^{28}$

The choice of battle range is a conscious decision of the ship's designers. As a first order estimate, every inch of belt armor removed saves enough weight to add about $1 / 3$ inch of deck armor. Removing one inch of belt will reduce the vertical Immunity Zone by about 1,000 yards, while adding $1 / 3$ inch of deck armor will increase the horizontal Immunity Zone by about the same distance. A given tonnage allocated for protection yielded a given width of Immunity Zone, which the designer could center as desired.

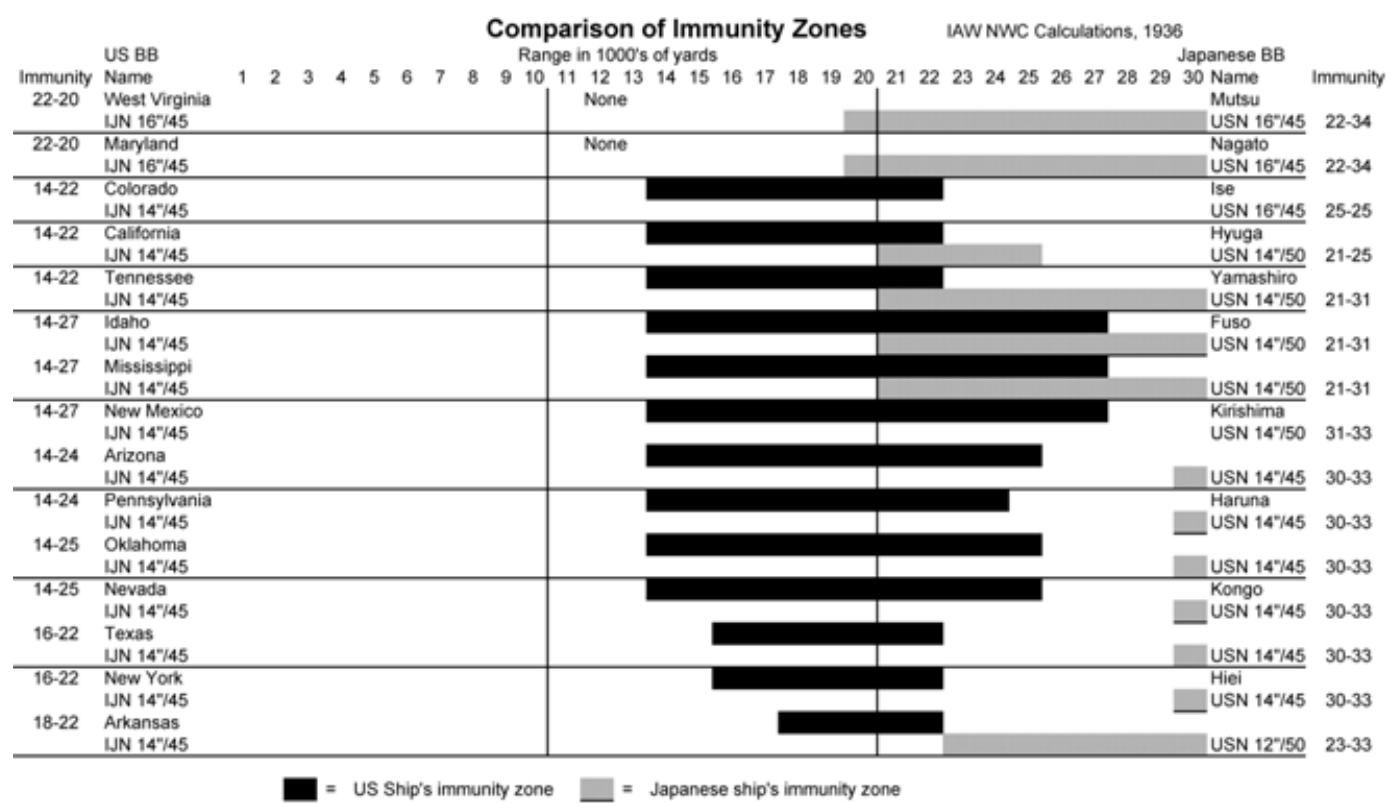

Chart 2: Comparison of Immunity Zones

Since the U.S. Treaty battleline consisted of fifteen ships as opposed to ten Japanese, the last five ships in the Japanese battleline (Fuso, Kirishima, Haruna, Kongo, and $\mathrm{Hiei}$ ) were assumed to split their fire and engage two targets simultaneously, to prevent any battleship "not under effective fire" from being awarded a twenty percent bonus to their gunfire accuracy. For example, Fuso would be required to split her fire between Idaho and Mississippi. The horizontal lines show the pairing of targets in the analysis.

The total life of the U.S. treaty battleline was calculated at 255.6 equivalent

28 Later, with the introduction of radar-directed fire control, the presumed maximum range of effective fire would extend beyond 30,000 yards. 
penetrating 14-inch hits and the Japanese at 150.6, a ratio of 10:5.89, quite close to the Treaty's 10:6. The total number of heavy caliber guns, 160 versus 96 , is similarly close to the Treaty ratio. As seen in chart 1, there is a significant difference in Immunity Zones. The U.S. fleet favored Immunity Zones at closer ranges than the Japanese. This reflected the combat philosophies of the two fleets. The Japanese believed that their long range gunnery was superior to the Americans', and so they intended to fight at long range. ${ }^{29}$ During fleet modernizations the Japanese added heavier deck armor to their ships for added protection at their preferred ranges. As their battle line had a speed advantage, fighting at longer ranges would also allow them to break off the action more easily if the battle did not progress in their favor.

In contrast, the Americans emphasized heavier belt protection, and, in general, protection over speed, so their ships tended to be more stoutly built and heavily armored than the Japanese, but slower. The Americans felt that long range engagements would not be decisive because most battleships carried only a hundred rounds per gun (or fewer) for their main batteries. Rate of fire was dependent upon the maximum mechanical rate of fire of the guns and the range to the target, since the process of spotting the fall of shot took longer at longer ranges due to time of flight of the projectiles. According to N.W.C. calculations, 100 rounds were enough for approximately 120 minutes of fire at 26,000 yards for 16-inch and 14-inch guns, or, in the Tactical Game, forty turns of three minutes duration. The Blue force would need to destroy the enemy battleline at a rate exceeding .025, or 2.5 percent, per turn.

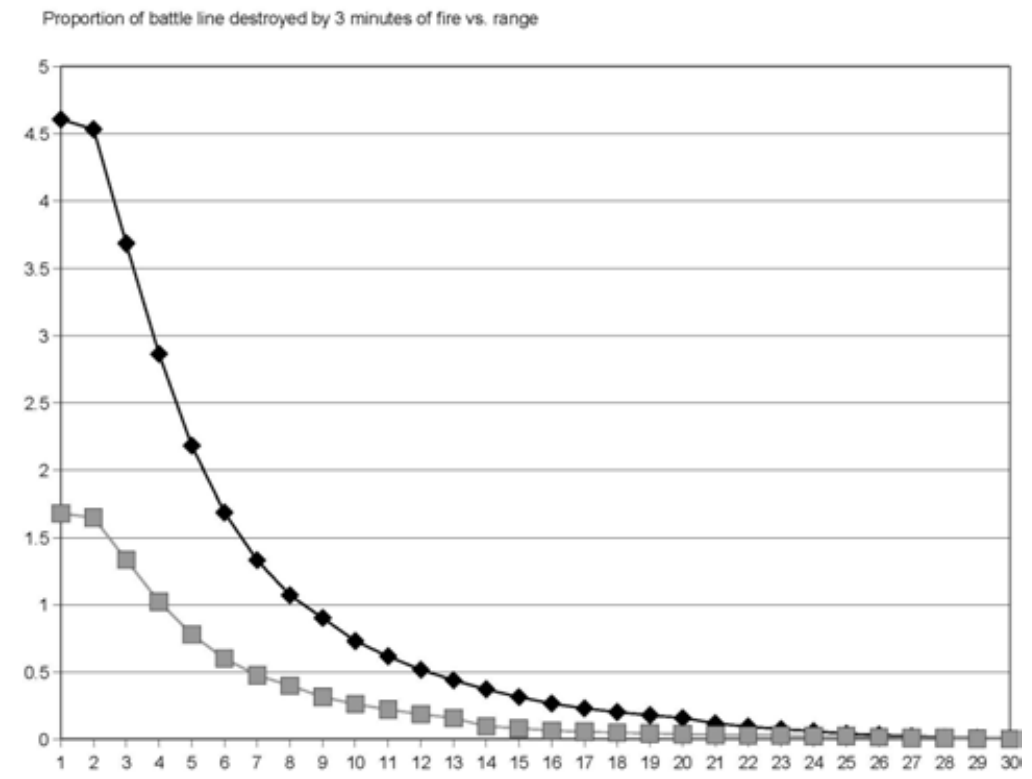

Chart 3: Losses as a proportion of battleline Life v. Range

Chart 3 shows a plot of the proportion of the battleline that would be destroyed per three minute turn with respect to range at the beginning of an engagement under

29 Evans and Peattie, 238 - 262. 
standard conditions of fire. This plot assumes that all the ships in the battleline are at the same range, that fire is distributed properly among the targets, the range has been established, the weather is good, and there are no penalties taken on the effectiveness of the fire. The upper line with diamonds at each data point shows the firepower of the U.S. battleline, and the lower line with squares the Japanese battleline's firepower. A value of "1" would mean that, at the given range, three minutes of fire would totally destroy the enemy battleline. For Blue to destroy the Orange battleline in forty turns of fire under standard conditions (and assuming no damage to the Blue force), the range would have to be less than 26,000 yards under ideal conditions; under battle conditions, and considering all of the 32 legal-sized pages of rules detailing how the accuracy and rate of fire might be reduced or penalized, a more reasonable estimate would be 20,000 yards or less. ${ }^{30}$

The "standard" conditions of fire result in a higher estimate of fire effectiveness than would actually be achieved. The N.W.C. Maneuver Rules include a myriad of correction penalties to account for factors that would degrade accuracy and rate of fire. According to the 1940 rules, accuracy penalties could be assessed if the firing ship changed course or speed, the target ship changed course or speed, if a firing ship or target ship was under concentrated fire, if stack gasses or other smoke interrupted the line of fire, if fire was halted and then resumed, if fire was shifted between targets, if the ship was surprised or had insufficient advance time to track the target before firing, if the ship was undergoing excessive pitch, roll, or yaw, if sea spray impinged on the directors, if secondary batteries were firing (at night), if guns were under local control rather than director control, if fire was masked by other friendly ships, or if the range was changing too quickly. Penalties totaling 50 percent to 90 percent were common when playing out a tactical situation.

An additional consideration was damage: if a gun was considered hit and placed out of action, the remaining ammunition for that gun would not be available. In addition, firing until the last available round was expended was unreasonable - any prudent commander would break off combat, retaining a reserve of ammunition for emergency self-defense. Since the Americans expected to be operating far from their bases, ammunition resupply would be problematic, so they wanted to achieve decisive results before more ammunition was needed. These factors all added to their desire to fight at closer ranges.

The American Navy did not ignore the potential of long range fire. They believed that the force that hit first would have a significant advantage. Salvos were not independent events. Their accuracy depended a great deal on the accuracy of the preceding salvoes, using the plot of the difference between shell fall and target location to achieve an accurate plot of the movement of the target and to apply corrections specific to the current conditions at the ship's guns. Consequently, the fleet engaged in Long Range Battle Practice with ranges that exceeded their preferred engagement ranges, firing at 21,000 yards in 1921, and progressively moving out to 27,000 yards by $1935 .{ }^{31}$ But

30 Naval War College, Maneuver Rules: June 1940; Section F: Gunfire, Naval War College RG4, Box 95, Folder 2268-B.

31 Bill Jurens, letter to the author, 24 September 2008. 
physics, the natural dispersion of ballistic rounds, and the performance of optical rangefinders and visual spotting put limits to the accuracy of such fire. So, while the Americans could engage at such extended ranges, they still expected decisive actions to be at shorter ranges.

Putting together all these factors, American naval officers calculated that decisive ranges were in the order of 20,000 yards or less. This led them to build ships with Immunity Zones mostly between 14,000 to 24,000 yards.

The difficulty was that the American battleline was considerably slower than the opposition. The American battleline would be restricted by the top speed of the Oklahoma, which the N.W.C. database gave as 19.6 knots, while the database credited the slowest Japanese unit, Fuso, with 22.5 knots, nearly a three knot advantage for the Japanese. The four Japanese battlecruisers were all assessed at 26 knots. In fact, these were underestimates: Fuso as reconstructed could make 24.7 knots, and the battlecruisers (as reconstructed into fast battleships) could sprint at 30.5. ${ }^{32}$ The Japanese would be able to establish and hold whatever range they preferred, unless damage intervened.

The Americans accepted the speed disadvantage. Since the American fleet would be advancing across the Pacific it would be incumbent upon the enemy to confront them. Their advance, they felt, could not be stopped unless the Japanese pressed into decisive range; in their view decisive range was close range.

Thus, the U.S. ship's Immunity Zones were considerably different than those of the Japanese.

Chart 4, "U.S. Battleline v. Japanese Battleline, Relative Fighting Strength," shows the results of the calculation of Relative Fighting Strengths using the N.W.C. methodology. In the calculation, the ships are paired off at the given ranges at a ninety degree target angle, using director-controlled fire and top spotting, for a single threeminute period of standard fire. The value of the U.S. fire is totaled and divided by the total life of the Japanese battleline, which gives the percentage of loss to the Japanese battleline. This procedure is repeated to obtain the percentage of loss to the U.S. battleline after three minutes of Japanese fire. The Japanese percentage loss is then divided by the U.S. percentage loss, to get a relative capability. A value of "1" would mean that each side is destroying an equal percentage of the enemy's force at that range. A value of "2" would mean that the Japanese percentage of loss was twice that of the U.S. battleline.

As seen on the plot, the U.S. Treaty battleline would be expected to defeat the Japanese Treaty battleline at all ranges, and by a significant margin. Between 13,000 to 22,000 yards, the ranges the Americans believed to be decisive, the U.S. forces inflict about four times the percentage of damage that they receive per turn, largely driven by the American ships' Immunity Zones. The most favorable zone for the Japanese would be at ranges over 25,000 yards, but still, the U.S. battleline would be inflicting damage twice as fast as it sustained it.

32 A.J. Watts and B.G. Gordon, The Imperial Japanese Navy (Garden City, 1971), 40 - 61. 
A value of " 4 " did not mean that the results of the full engagement would have losses in a ratio of 4 to 1 . This number represents the ratio of the damage in the first minutes of the battle under standard conditions. The final results would likely be much worse for the inferior force, since it would lose firepower at the faster rate. For example, with a 4:1 initial ratio the American battleline might take one turn of 2.5 percent damage, and the Japanese battleline 10 percent, so for the next turn the Americans would have 97.5 percent of their fire remaining, to 90 percent fire remaining to the Japanese, and the subsequent loss ratio would be 4.33 to 1 . As the battle progressed, the ratio would be expected to go higher, 6:1, 8:1, and more. According to Lanchester equations, the final results would be in accordance with the square of the initial ratio, so if a battle was fought in the 4:1 range band to the total destruction of the Japanese battleline, the U.S. force would be expected to suffer only one sixteenth the losses of the Japanese. ${ }^{33}$ This would certainly reflect a decisive victory for the American battleline.

According to these calculations, which mirror similar studies performed at the war college, American naval officers had every reason to be confident that their Treaty battleline would prevail in a fleet engagement.

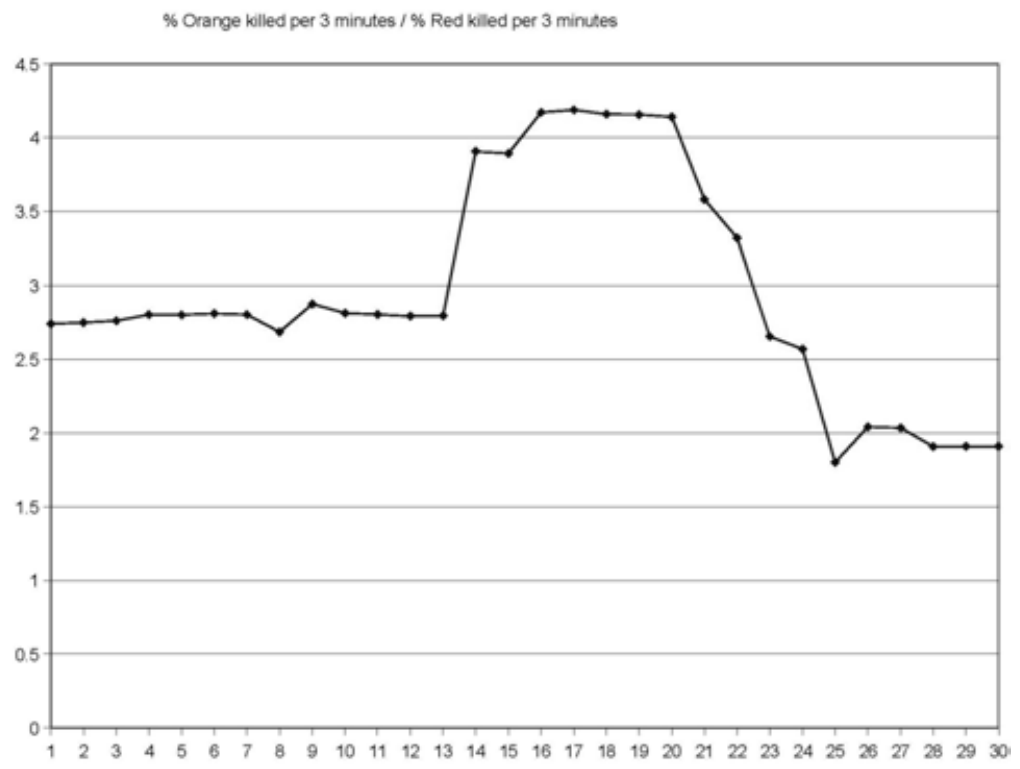

Chart 4: Rate of Japanese damage divided by rate of U.S. damage

Chart 5, the next plot of Relative Fighting Strength, shows three lines. The top line with diamonds at the data points shows the relative fighting strengths of the Treaty fleets, a repeat of the line shown in chart 4 . The next line down, with squares at the data points, shows the Relative Fighting Strengths on 1 April 1942, four months after the Pearl Harbor attack. The five sunken battleships are removed from the calculation, while the new battleships Washington and North Carolina are added. As can be seen, there is a

33 Philip M. Morse and George E. Kimball, Methods of Operations Research (New York, 1950), $63-77$. 
significant drop in the Relative Fighting Strength of the U.S. battleline at all ranges. However, the Blue battleline still maintains a decisive advantage in Blue's preferred range band, inflicting damage at twice the initial rate as it would be receiving. This advantage drops off rapidly at ranges greater than 20,000 yards, mainly because of the Orange battleships' better deck protection. But it still remains above 1 .

The bottom line shows the Relative Fighting Strengths after applying a thirty percent (subtractive) reduction to Blue Hitting Power, to reflect the U.S. assumption that there would be a thirty percent reduction in fighting effectiveness because of the 3,000mile distance separating the fleet from its primary bases. In Blue's preferred range band the U.S. advantage remains substantial, greater than 1.5 , but at ranges shorter than 13,000 yards or longer than 23,000 yards the fleets are nearly equal.

Another factor was the capability of a ship to stand in the line of battle. Arkansas was armed with 12-inch guns that could only range to 23,000 yards; New York and Texas never had their 14-inch main batteries modernized and could only fire to 22,000 yards. All three were reaching the end of their service life, so they had not been maintained to the same standards as the other units, and were considered unfit to occupy a place in the battle line. Without them, the relative Fighting Strength of the battleline would drop by approximately another 15 percent at ranges under 22,000 yards, and the Blue Relative Fighting Strength would be equal to or less than that of Orange over significant range bands.

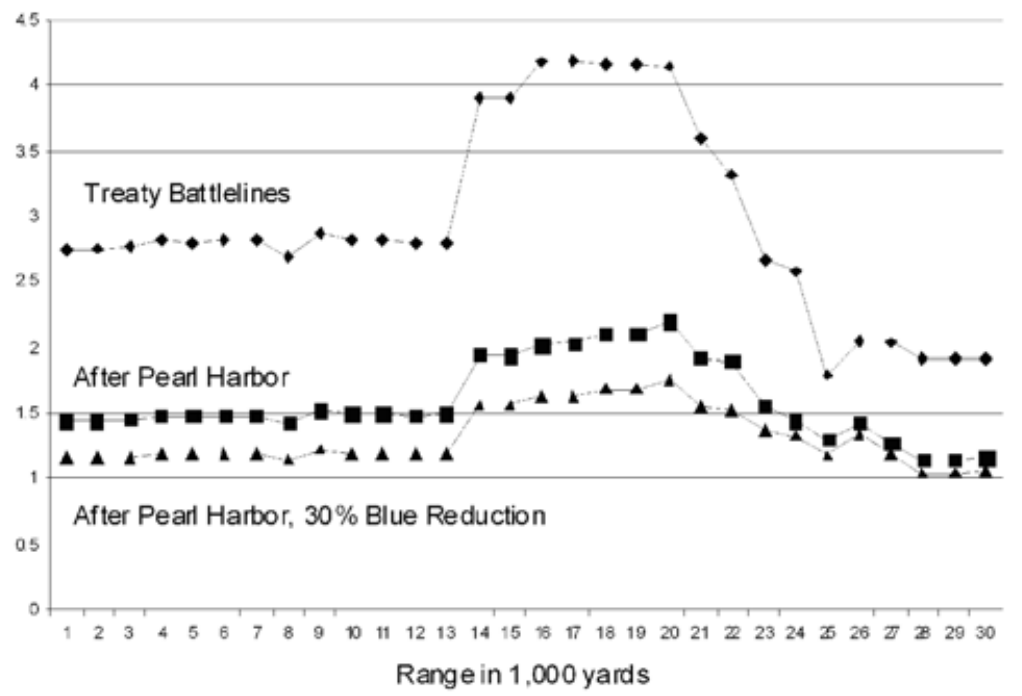

Chart 5: Relative fighting strength before and after Pearl Harbor

Calculations such as these were held in much esteem by the officers of the United States Navy - they were a part of what Ronald Spector termed "Applying the 'Science of Naval Warfare." ${ }^{34}$ Plots of the Relative Fighting Strength of the battlelines were

34 Ronald Spector, Professors of War: The Naval War College and the Development of the Naval Profession (Newport, 1977), 130. 
calculated on a regular basis - many still exist in the archives at the Naval War College. Normally, the Fighting Strength values for ships on a one-on-one basis fell within ten percent. If a foreign warship was twenty percent higher than its opposite number in the battleline (or equivalent class, for cruisers), it was a matter for serious concern and often resulted in a re-evaluation of American ship designs or a modernization program. When the British battleship Nelson appeared with superior deck protection and a larger and longer-ranged main battery than the most powerful U.S. Treaty battleship, and scored 1.8 in some range bands, it caused great concern.

Important use was made of these types of calculations. For example, Fighting Strength figures were performed to support U.S. policy decision making at the London Naval Conference of 1930. The 1933 proposal for a class of American battlecruisers was abandoned largely on the basis that the design scored only in the $0.75-0.90$ band when compared to opposing Japanese battleships. The N.W.C. calculations helped inform the decisions in selecting heavy cruiser and battleship designs from among engineering preliminary designs, and were instrumental in killing the proposed flight deck cruisers of the late $1930 \mathrm{~s} .{ }^{35}$

Fighting Strength Calculations, the basis of the war game program, formed a significant part of the worldview of senior American naval officers. Admiral Sims, the First World War commander of U.S. naval forces in Europe and later the president of the Naval War College, wrote that

The principles of the war game constitute the backbone of our profession ... At the Naval War College our entire fleet ... can be maneuvered on the game board week after week throughout the college year, ... all operations being governed by rules ... that the students are required to learn. ... In no other way can this training be had except by assembling about a game board a large body of experienced officers divided into two groups and "fighting" two great modern fleets against each other - not once, or a few times, but continually until the application of the correct principles becomes as rapid and as automatic as the plays of an expert football team. ${ }^{36}$

During the Depression years the officer corps was shrinking, and competition for promotion was intense - each step up the ladder from lieutenant to rear admiral exacted 50 percent to 75 percent attrition or more. Good performance in war games was one key to promotion, and that required hard work and thorough study of the war game rules. Study was intense, on a six-day per week schedule. One civilian observer stated that the difference between the N.W.C. and the other service colleges was that the N.W.C. library was crowded at $7 \mathrm{pm}$. In the 1920s, the N.W.C. libraries checked out an average of 83 volumes per student per year, apart from their regular textbooks. ${ }^{37}$ By 194199 percent of

35 Alan D. Zimm, “The U.S.N.'s Flight Deck Cruiser," Warship International No. 3 (1979). Also R.D. Layman and Stephen McLaughlin, The Hybrid Warship: The Amalgamation of Big Guns and Aircraft (London, 1991), 95 - 99.

36 Francis J. McHugh, The United States Naval War College Fundamentals of War Gaming (Springfield, VA., 1966), 2 - 53.

37 John B. Hattendorf, Sailors and Scholars: The Centennial History of the U.S. Naval War 
all admirals, and most of the admirals who would command during the Second World War - men such as King, Nimitz, Spruance, Halsey and Turner - had attended the college, with Turner serving there for a second tour and Spruance for a second and third tour as instructors. ${ }^{38}$ And they were true believers. Often quoted is the statement from Fleet Admiral Nimitz that

The war with Japan had been enacted in the game rooms at the War College by so many people and in so many different ways that nothing that happened during the war was a surprise - absolutely nothing except the kamikaze tactics toward the end of the war. ${ }^{39}$

Less well known is the statement by Vice Admiral James Stockdale in 1979: "The reputation of the Naval War College was built largely on the tremendous impact gaming had on World War II." ${ }^{\text {"40 }}$ The games and rules were classified, so no naval officer of the period discussed the system in any detail in open sources. The technical nature of the computations and the games are outside the comfort zone of most historians, and thus, the Fighting Strength Calculations have been largely ignored. However, it was part of the foundational education of senior officers, and if not constantly in the forefront of their minds, it continually influenced attitudes, perceptions, and ways of thinking.

\section{The possible influence of Fighting Strength calculations on decisions regarding the employment of the battle fleet, December 1941 to June 1942}

The Relative Fighting Strength calculations shown in chart 5 is a lens into a component of the decision making process immediately following Pearl Harbor. It provides a better understanding of parts of the foundation upon which U.S. naval leaders made critical decisions regarding the deployment and use of the battleline in the first six months after the American entry into the war.

Chart 6 shows the strategic situation regarding battleships on 6 December 1941, giving each battleship's general location or operating base. The number of operational battleships is shown inside circles, while ships in the "pipeline," that is, not battle-worthy, meaning that they were under repair, under construction, or undergoing workup training, are shown in squares. Axis battleship numbers are shown on shaded symbols, Allied on white symbols. The inset tables show Atlantic and European Theater and Pacific Theater totals. Mediterranean Theater totals, a subset of the Atlantic totals, are also shown. The worldwide totals are summed; the summary boxes are shaded depending on the side with the numerical advantage.

The plot in the lower right hand corner shows the expected totals of ships for the

College (Newport, 1984), 121.

38 See Potter, Nimitz; Vice Admiral George Carroll Dyer, The Amphibians Came to Conquer: The Story of Admiral Richmond Kelly Turner (Washington, 1969); Ernest J. King and Walter Muir Whitehill, Fleet Admiral King: A Naval Record (New York, 1952); Thomas B. Buell, The Quiet Warrior: A Biography of Admiral Raymond A. Spruance (Annapolis, 1974); also Vlahos, 92.

39 Dr. Donald C. Winter, speech to Current Strategy Forum, Naval War College, 13 June 2006.

40 Vlahos, 160. 
current and next five months. It assumes that pipeline ships will return from repairs or be commissioned and trained as scheduled, and that no other ships will be placed out of commission by battle damage or go into refit or overhaul. Certainly, this last assumption would not be expected to hold true, but the chart does allow an examination of the margin that the two sides would be considering when plans were made for operations, overhauls and refits. For new construction ships, or ships returned from yard periods exceeding six months, a two-month workup period was assumed after commissioning. This was considered the minimum training period a ship's crew would require to attain minimum combat effectiveness. It also served as an operational shakedown period to ensure all ship's systems were operating properly; often ships were returned to the shipyard to correct deficiencies. Ships might be committed to combat before shakedown and workups were complete, the most famous example being when the British battleship Prince of Wales went into battle against the German battleship Bismarck while there were still shipyard workers aboard correcting defects in the main battery guns and other systems.

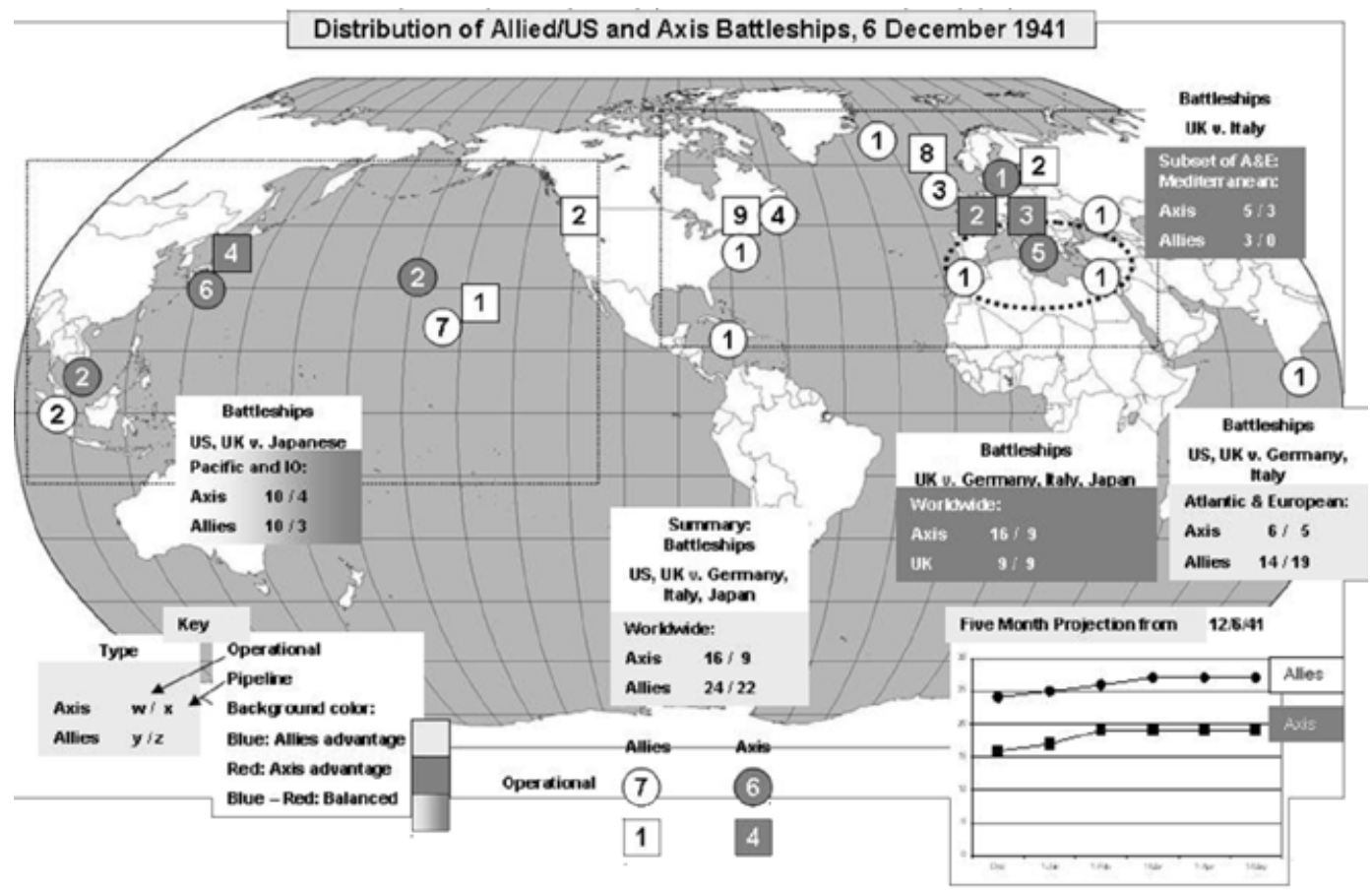

Chart 6: Battleship deployments before Pearl Harbor

In lining up the British against the Germans and Italians in the Atlantic and Mediterranean, the British held a slim nine to six advantage. This was ameliorated by the fact that most of the opposing battleships were Italian, which suffered from fuel shortages, were constrained geographically, and were not aggressively handled. Great Britain had nine additional battleships in the pipeline, three new construction and six under repair (one in US yards), the number under repair reflecting the intensity of the war at sea. But the British situation was projected to improve over time, considering the 
numbers of battleship additions and returns to service compared to the ships in the pipeline for Germany and Italy.

If Japan should join the war against Britain without bringing the United States into the conflict, Britain's battle fleet would be seriously outnumbered. Maintaining a local superiority of battleships in home waters to protect the Atlantic lines of communications from raids by German battleships and battlecruisers would mean accepting inferior numbers in all other theaters. Pipeline numbers would be equal, should the Germans and Italians press on to return their damaged ships to service.

Should the United States enter the war, the situation would change dramatically. Not only would the Allied forces outnumber the Axis by twenty-four to sixteen in operational battleships, but the Allies would have an even greater superiority when the twenty-two battleships in the pipeline become available. While some of these warships were years away from availability, the five month projection (shown on the lower right of the chart) shows the combined Allied forces maintaining a comfortable overall margin over the short term.

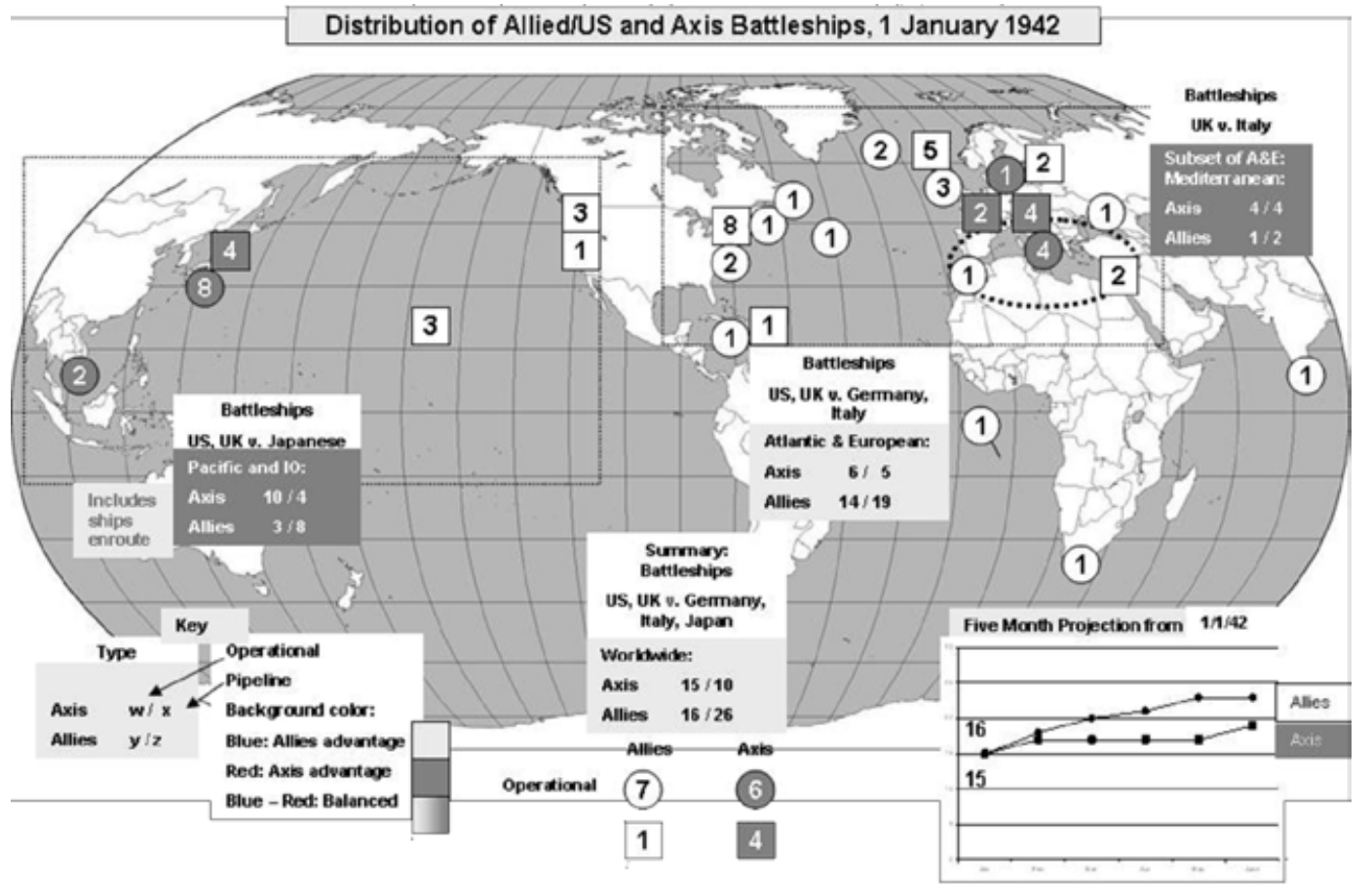

Chart 7: Battleship deployments, 1 January 1942

Chart 7 shows the dramatically changed situation on 1 January 1942. Taken away from the former Allied operational total are the five battleships disabled at Pearl Harbor, along with the Prince of Wales and Repulse sunk off Singapore. Three battleships from Pearl Harbor are undergoing repairs, while two other British battleships, Queen Elizabeth and Valiant, sunk in December 1941 by Italian frogmen in Alexandria harbor, are in the process of being salvaged. The only Axis damage was to the modern Italian battleship Vittorio Veneto, in the shipyard to repair torpedo hits from a British 
submarine. With Japan joining the Axis and the spate of Allied losses, the battleship forces are numerically equal, fifteen apiece. As shown in the five month projection chart, the Allied numbers would recover at a steady rate, but the Axis threat would also be growing, with two German battlecruisers returning to service in January, Vittorio Veneto repaired by June, and the Japanese battleship Yamato becoming combat ready in May.

The distribution of Allied battleships is most significant. In this snapshot more than three weeks after Pearl Harbor, the Pacific is completely without operational American battleships. The number of Allied battleships in the European Theater has only dropped by one, a movement of one additional battleship into the theater counterbalancing the loss of two battleships at Alexandria. U.S. battleships in the Atlantic show a net movement to the northeast, operating out of Casco Bay in Maine and Iceland to cover better the Atlantic lines of communications. Some of this force deployment was in reaction to the imminent return to operational status of the German battlecruisers Scharnhorst and Gneisenau, located at Brest in southwest France, and the threat that they would resume raiding operations in the Atlantic. But, given all these considerations, there remains the rather shocking observation that no American battleships had arrived in the Pacific.

One possible reason for this comes from looking at the conduct of war games at the Naval War College. Among the strategic games fought by each class of students and in support of analytical studies, there are no records of games where the Japanese moved battleship forces into the Eastern Pacific. The expectation, the worldview drummed into the future U.S. commanders, was that the U.S. force would have to move west and beat the enemy in his home waters. Any such movement was well in the future, requiring a buildup of the battleline and the assembly of a large logistics train. Given that expectation, it would be natural to consider where the battleships could be put to productive use while awaiting the prerequisites for operations in the Western Pacific. This logic would lead to making the battleships available to support Great Britain and the defense of the Atlantic sea lines of communications (SLOC) as a first priority, especially considering the pre-war "Germany first" agreements between the Allies. The Pacific would just have to await the recovery of the battle fleet.

Not that the Pacific Fleet would be inactive - the Pacific Fleet plans had always included a period when the aircraft carriers were sent out on raiding expeditions against the Marshalls and other forward Japanese positions. The original plans included battleship support, in the event that Japanese battleships should sortie against them. However, with the bulk of the Japanese battleline assessed by naval intelligence as remaining in home waters, this proved unnecessary. It was always accepted that there would be a period of delay in U.S. Pacific Fleet operations while supplies and a logistics train was collected. The problem was, with the demands of the war in Europe, this logistics train just was not available, and would not be available for the foreseeable future. To prevent further depradations against shipping, the battleships were first committed in the Atlantic.

The activity of the carrier forces, and the relative inactivity of the battleships, might lead many to draw erroneous conclusions regarding whether the battleship was 
considered an effective fighting unit. They were effective, and needed, but just not yet ready to move against the Japanese.

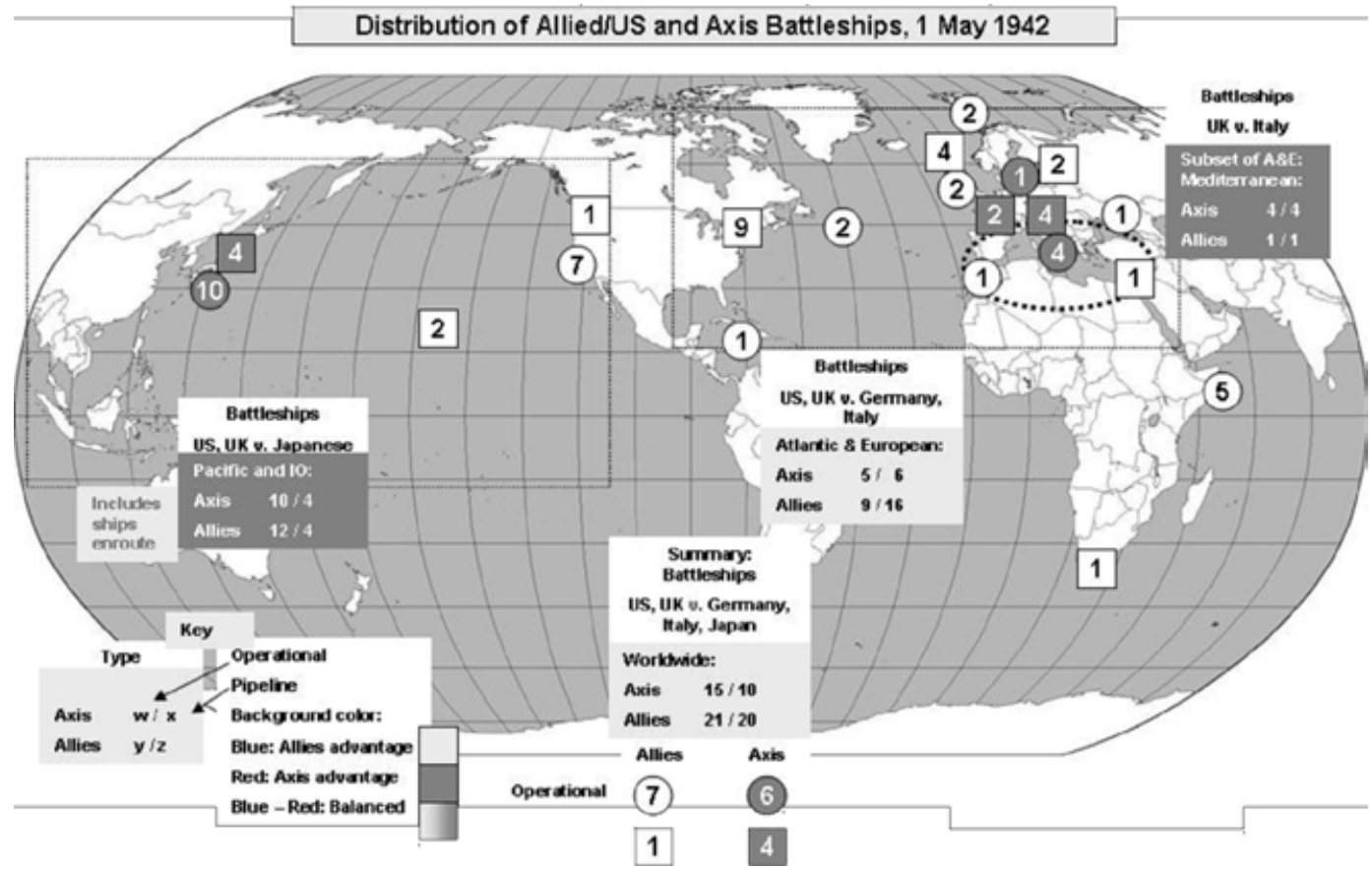

Chart 8: Battleship deployment, 1 May 1942

By May 1942 the situation had changed, as shown in chart 8. The two German battlecruisers were damaged in their run through the English Channel returning to Germany and were out of action, leaving only the German Battleship Tirpitz as a threat to Atlantic shipping. Even so, not counting the Soviet battleship in the Black Sea, the Allies retained seven battleships in the Atlantic to counter this single warship.

There were several reasons for this concentration of power. First was the importance of countering the Tirpitz, considering the continued perilous state of Atlantic shipping under pressure by packs of U-boats. Tirpitz was faster than many of the Allied battleships, so it would likely take a number of units to corner her and force her to battle. Carriers had limited utility in Arctic waters, because of unfavourable weather and, for half the year, long hours of darkness. Second, there was no evidence of an imminent movement by the Japanese battle fleet to the eastern Pacific, and insufficient logistical support for the U.S. battle fleet to push into the western Pacific. Third, the war college methodology for calculating the relative strengths of the Japanese and American battlelines showed that the U.S. battleship fleet was not yet sufficiently powerful to risk a major action. These last two considerations lead to the conclusion that offensive operations in the Pacific by the battleline would best be deferred.

As shown in chart 5, a few months after Pearl Harbor the full American battleline had the power to defeat the full Japanese battleline with any confidence only if the U.S. battleships were concentrated, and the engagement was in the Central Pacific, on "neutral 
ground," distant from both sides' bases. In such an engagement, the American losses would likely be ten to twenty-five percent of their initial Fighting Strength if it was fought at decisive ranges.

This confrontation would occur only if the Japanese battleline moved east. They attempted to do so at Midway in June of 1942, only to have their carrier support stripped away and sunk. In that battle, the available portion of the American battleline, Task Force 1, sortied from San Francisco and took a position approximately 1000 nautical miles to the northeast of Pearl Harbor. The battleships were positioned to move in either of two directions: toward the east, to counter two Japanese battleships and a carrier that were reported to be intent on raiding California, or to the west, to intervene in the operations around Midway. The battleships were not assigned directly to the carrier task forces because they were too slow and would inhibit the carriers' freedom of action.

In fact, the Japanese force that moved against the Aleutians (the likely source of the report of the threat to California) actually had four battleships and two carriers. Admiral Yamamoto retained three battleships and four battlecruisers with the Midway invasion forces. Yamamoto violated a Mahanian injunction never to split the battle fleet; however, Yamamoto was never a particular fan of Mahan. ${ }^{41}$

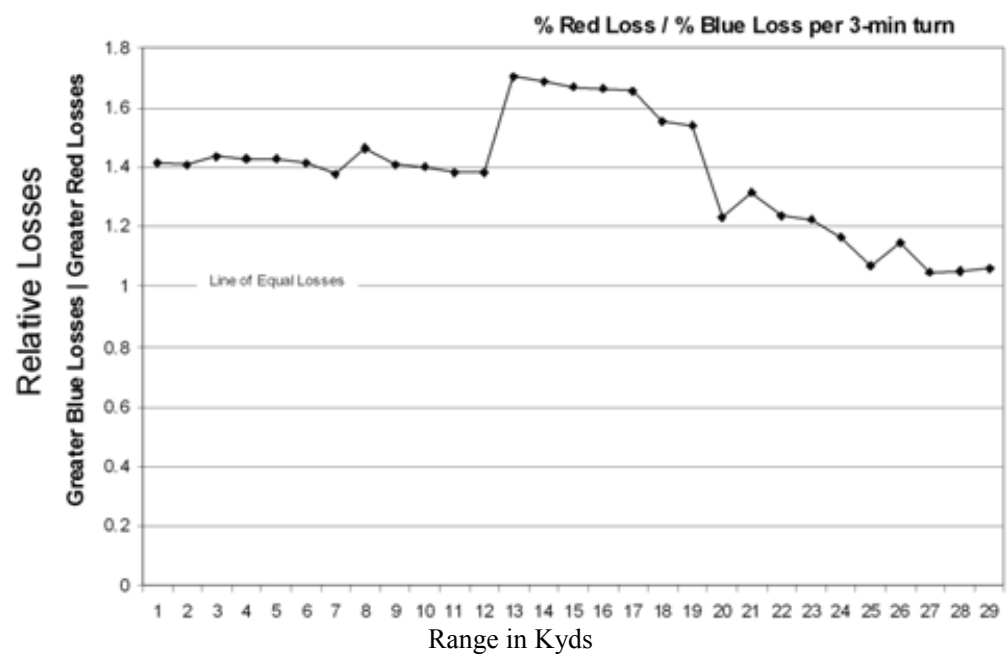

Yamato, Mutsu, Nagato, Haruna, Kirishima, Kongo, Hiei versus

Colorado, Maryland, Tennessee, Idaho, Mississippi, New Mexico, Pennsylvania

Chart 9: Relative Fighting Strengths of the possible Battlelines at Midway

For a short time after the four Japanese carriers with the Midway attack forces were sunk, Yamamoto considered continuing the offensive with his surface ships, covered by the fighters from only one small light carrier. Had he persisted there could have been a confrontation between Yamamoto's part of the Japanese battleline and Task Force 1, seven ships against seven. Without considering factors other than battleline versus battleline, according to the N.W.C. calculations shown in chart 9, this was a battle the Americans could have won.

41 Asada, 17. 
After Midway, the Japanese battleline remained in a more defensive deployment. If Blue wanted a battleline engagement, it would have to seek it out. However, if a concentrated Blue fleet went west to engage in battle near the Japanese home waters in 1942, the outcome would have been close, perhaps "too close to call." The Fighting Strength calculation gave victory to the Blue force, but with fifty to seventy-five percent losses likely. That level of potential losses dictated a need for forward bases to eliminate the "thirty percent penalty" on the force's Fighting Strength, and to be able to salvage and repair ships damaged in such an engagement. These considerations supported those officers who favored a systematic advance across the Pacific. It also provided computational data to counter the arguments of the "thrusters" who wanted an immediate leap to the Philippines, ${ }^{42}$ an approach that had been eliminated in any case by the lack of tanker and cargo shipping to provide the huge logistics support such a move would require.

And, perhaps in the back of some minds was the specter of Tsushima. A Russian fleet had sailed half way around the world to be met by the Japanese who, after patiently waiting for them near their homeland, crushed them.

There were other factors that came into play in deciding the dispositions of the battle fleet. First, the Americans knew that time was on their side because of the United States' advantage over Japan in industrial capacity. U.S. intelligence believed that the Japanese had only two battleships in the pipeline as of May 1942. ${ }^{43}$ The U.S. Navy by contrast, had eleven battleships in the works, including new construction and ships salvaged from Pearl Harbor. Second, the pace of the war in the Pacific was largely dictated by logistics. Not only did logistics prevent any immediate major trans-Pacific move, fuel was a constant, nagging concern in the daily life of the carrier task forces. All the ships were burning more fuel than anticipated. The days when ship's engineers brought out all their ploys and tricks to make a good showing in the annual fuel endurance competitions were long gone - now, boilers had to be kept hot in preparation for emergency demands for high speeds, tubes could not be kept so clean, packing glands not maintained so tight, distilling units ran overtime - fuel consumption could be fifty percent more than anticipated. There were limited numbers of fast fleet tankers available to the Pacific fleet (only four in the first months of the war), and the fast-moving carrier task forces burned oil at a prodigious rate. A shuttle of commercial tankers (initially three ships) from California to Pearl Harbor could not keep the storage tanks there filled. Counting all the storage available between Pearl and Australia would provide fuel for

42 Edward S. Miller, War Plan Orange: The U.S. Strategy to Defeat Japan, 1897-1945 (Annapolis, 1991).

43 Yamato (operational in May of 1942) and Musashi (to be commissioned in August of 1942). Shinano and Hull No. 111 were also under construction in May of 1942. Shinano would eventually be converted to an aircraft carrier after the Midway debacle; Hull No. 111 was to be cancelled on the ways due to a lack of steel and the need to divert shipbuilding capacity to escorts and cargo shipping. Naval intelligence may have had indicators of these additional new construction battleships, but they were not considered strong enough to list the ships in ONI 41-42. 
Task Force 1 for twenty-nine days at cruising speed or ten days at full speed unacceptably low, considering that there were three other carrier task forces with similar consumption rates also with a call on those resources. Under these handicaps, there simply was insufficient fuel flowing to the forward areas to support current operations and build up a reserve, much less support fuel-hungry battleships. ${ }^{44}$

Food was also a problem. By early March provisions were short in the South Pacific, with only limited numbers of stores ships available for replenishment. At one point Task Force 11 wanted to take on supplies from the sole available South Pacific stores ship for a transit back to Pearl Harbor, but Admiral King ordered the force to eat "beans and hardtack" rather than draw on the forward supplies. The hardtack would likely have been welcome: Lexington was down mainly to a diet of beans and canned spinach. ${ }^{45}$ Moving the battleships forward, with 1500 to 2400 men per ship plus the crews of their supporting cruisers and destroyers, would have broken the slender reed of South Pacific supply. Supply ships were a critical resource and a serious shortfall, particularly with the U-boats still rampaging in the Atlantic. All other supply ships were committed to keeping Great Britain in the war.

As it was, when the old battleships began to move to the South Pacific in November 1942, after arrival they were mostly kept at anchor. Most had long periods with less than ten percent of their time spent training underway. Combat skills atrophied.

From the viewpoint of the conditions in early 1942, all these considerations coalesced to trace a clear course of action. There was no reason to move west prematurely to fight a battleline engagement that would have an uncertain outcome. In time, the industrial base would replace the losses at Pearl Harbor, and then some. So too would the industrial base make up the heavy losses in tankers and supply ships to U-boats in the Atlantic. In a year the reinforced battleline would regain its overwhelming superiority over the Japanese, if it was not frittered away in lesser actions.

It was logical for the U.S. battleline patiently to wait - its time would come.

Meanwhile, time could be put to good use. In May 1942, a battleship modernization program was announced that, among other things, took Tennessee and Pennsylvania out of service for extensive rebuilding and took other battleships such as Idaho, off the line for lengthy refits, all of which included sweeping improvements in their anti-aircraft capabilities.

All this would not come together - forces, supply, transport - until 1943.

\section{Conclusions}

Battleships were still a significant element of naval power in 1942, even after the debacles at Pearl Harbor and off Singapore. The assumption made by many that naval commanders had written off battleships as obsolete is incorrect. This assumption constitutes a misinterpretation of battleships' continuing central importance and the

\footnotetext{
44 Fuquea, 716.

45 Lundstrom, 95.
} 
reasons why they were not employed in the front lines of the Pacific war during 1942. The decisions holding back the battleships from employment in the Pacific in the first months after Pearl Harbor were based on rational factors. The U.S. battleline did not yet have a sufficient margin of power to ensure a victory, did not have the essential infrastructure of forward bases, and did not have the required logistics support.

The Naval War College Maneuver and Fires war gaming rules, and the associated Fighting Strength calculations, were analytic methods embedded in the worldview of U.S. Navy officers. Their intensive training and experience in those war gaming techniques informed their expectations of victory or defeat in engagements between specific combinations of forces. These calculations indicated that, after Pearl Harbor, the U.S. battleline was still likely to defeat the Japanese in an engagement in Eastern Pacific waters. However, the margin would have been much closer than what they were accustomed to seeing with the pre-war Treaty battlelines. The calculations indicated that any battle in the Western Pacific would have been close run. The shortage of logistics support in the Pacific, and the fact that the American battleline would become much stronger than the Japanese as time went on, dictated the decision was made to defer the movement of the battleship fleet into the Western Pacific. Significant numbers of battleships were retained in the Atlantic to support the British Home Fleet, where they could provide useful service in the interim.

Understanding calculations from the Naval War College analysis methods, a cornerstone in the professional development of senior U.S. Navy officers, is essential more fully to understand the decisions made by the naval leadership in deploying fleet units during the first six months of the war in the Pacific. ${ }^{46}$

46 The author would like to express his grateful thanks to the many respected experts, most of them authors in their own right, who took the time from their own work to review versions of this paper and provide substantive comments and constructive criticisms that resulted in great improvements: David Dickson, Bill Jurens, Michael Ley, Keith McBride, Vince O’Hara, Nathan Okun, Jon Parshall, Bill Schleihauf, Richard Worth. 


\section{APPENDIX 1: N.W.C. Formula}

The Life of a ship was determined in term of the number of equivalent 14-inch penetrating hits it could sustain before sinking. This was determined through the formula

$$
\begin{aligned}
& \mathrm{L}=\mathrm{A}\left(\mathrm{PR}^{1 / 2}\right)(\mathrm{BT})^{1 / 3} \\
& \mathrm{~T}=\text { tonnage, in } 1000 \mathrm{~s} \\
& \mathrm{~B}=\text { coefficient of above-water tonnage } \\
& \mathrm{A}=\text { coefficient of the characteristics of construction } \\
& \mathrm{R}=\text { ratio of the whole target area to vitals area } \\
& \mathrm{P}=\text { probability factor }
\end{aligned}
$$

After 1924 there was an additional bonus applied for modernization after commissioning.

Torpedo hits were also counted against the Life of a ship, with some particular rules. 21-inch surface and submarine torpedoes were generally given a value of three 14inch equivalents, and 18-inch aerial torpedoes a value of 1.5. A torpedo that hit within 15 minutes after an earlier hit was given a value 50 percent greater. No reason is given, but it is presumed that this is to account for the effects of damage control and counterflooding - near-simultaneous torpedo hits would be a danger to capsize the ship.

Bomb hits were given damage values also denominated in 14-inch equivalent hits. Their effect was divided into "above water" and "under water" damage, to be counted against weapons and command and control facilities for the former, and speed and buoyancy for the latter. Against battleships, a 1000-pound bomb had a value of 2.00 above water hits and 0.75 below water hits; a 500-pound bomb was valued at 1.00 and 0.25 , respectively; and a 100 -pound bomb at 0.15 and 0.00 . 
